\title{
Sutureless wound closure- our experience
}

Imran Pathan, Ravi Kumar Chittoria*, Saurabh Gupta, Chirra Likhitha Reddy, Padma Lakshmi Bharathi Mohan, Shijina K, Nishad K. Senior Resident Department of Plastic Surgery Jawaharlal Institute of Postgraduate Medical Education and Research (JIPMER) Pondicherry, India-605006

*Corresponding author: Ravi Kumar Chittoria, Professor Department of Plastic Surgery, Jawaharlal Institute of Postgraduate Medical Education and Research (JIPMER), Pondicherry India-605006: Email: drchittoria@yahoo.com

Received Date: January 10, 2020; Accepted Date: January 20, 2020; Published Date: January $24,2020$.

Citation: Pathan I, Ravi K Chittoria*, Gupta S, Chirra L Reddy, Bharathi Mohan P L. (2020) Sutureless wound closure- our experience. Surgical Case Reports and Images, 3(1): Doi: 10.31579/2690-1897/014

Copyright: () 2020. Ravi Kumar Chittoria. This is an open-access article distributed under the terms of the Creative Commons Attribution License, which permits unrestricted use, distribution, and reproduction in any medium, provided the original author and source are credited.

\section{Abstract}

Traditional techniques for wound closure are- Sutures (stitches), staples and adhesive tapes. Tissue adhesives have entered clinical practice more recently. Sutures enable the closure of the wound to be meticulous, but they have drawbacks. Sutures may show tissue reactivity and can require removal

Keywords: sutureless; wound, closure

\section{Introduction}

Traditional techniques for wound closure are- Sutures (stitches), staples and adhesive tapes. Tissue adhesives have entered clinical practice more recently. Sutures enable the closure of the wound to be meticulous, but they have drawbacks. Sutures may show tissue reactivity and can require removal. Tissue adhesives have the advantages that it does not require removal later and also there is no risk of needle stick injury. When launched first, tissue adhesives were used primarily in emergency room settings, but with the time tissue adhesives found there place in the operating room/theatre where surgeons are using them increasingly for the closure of surgical skin incisions.

Cyanoacrylates were first synthesized by Ardis. Coover et al discovered the adhesive properties of cyanoacrylate and suggested their use as surgical adhesives. Since then there has been interest in the use of cyanoacrylate as an alternative to sutures for surgical procedures

\section{Methodology}

This study was conducted in department of plastic surgery in a tertiary care centre. This study was conducted in Oct- dec, 2019. The case was of a 29 year female with chronic primary lymphedema of left lower limb with secondary grade 7 skin changes (WHO grading). After appropriate investigations patient was planned for vascularised lymphnode transfer using sub mental lymphnodes. Intra-operatively the submental vessels were found to be hypoplastic with short pedicle hence submental lymphonode transfer was deferred. Submental skin was closed using tissue adhesive (Histoacryl). (Figure 1 to 3 )

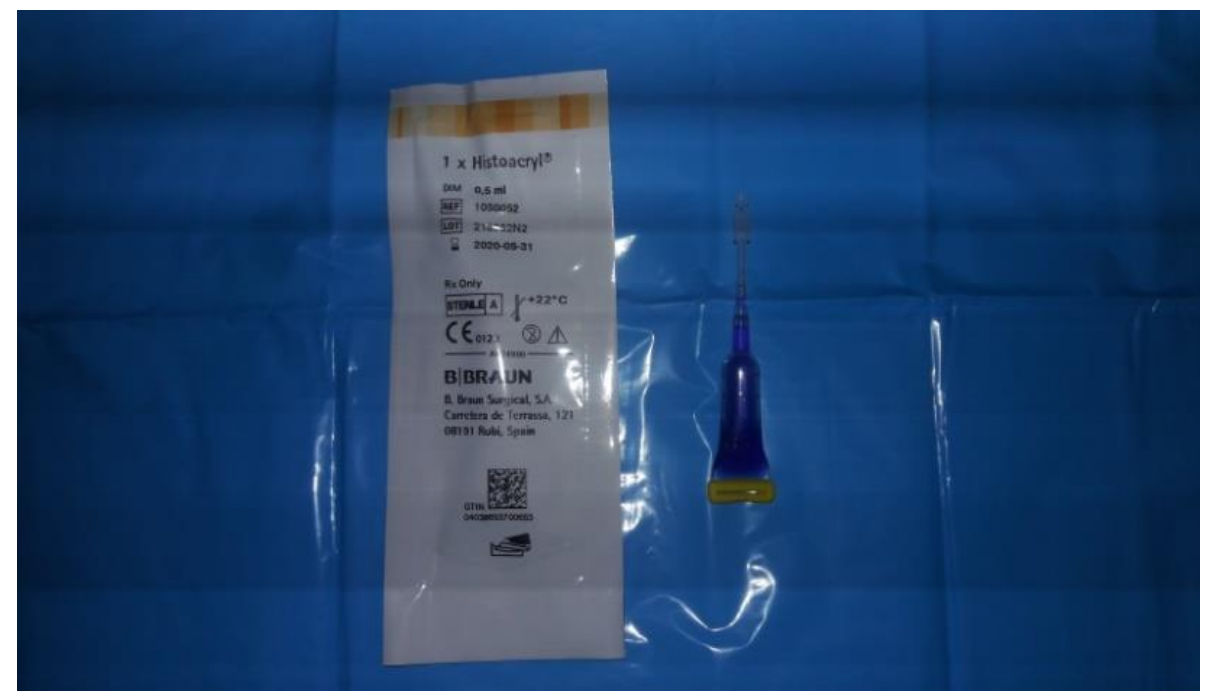

Figure 1. (Histoacryl) 


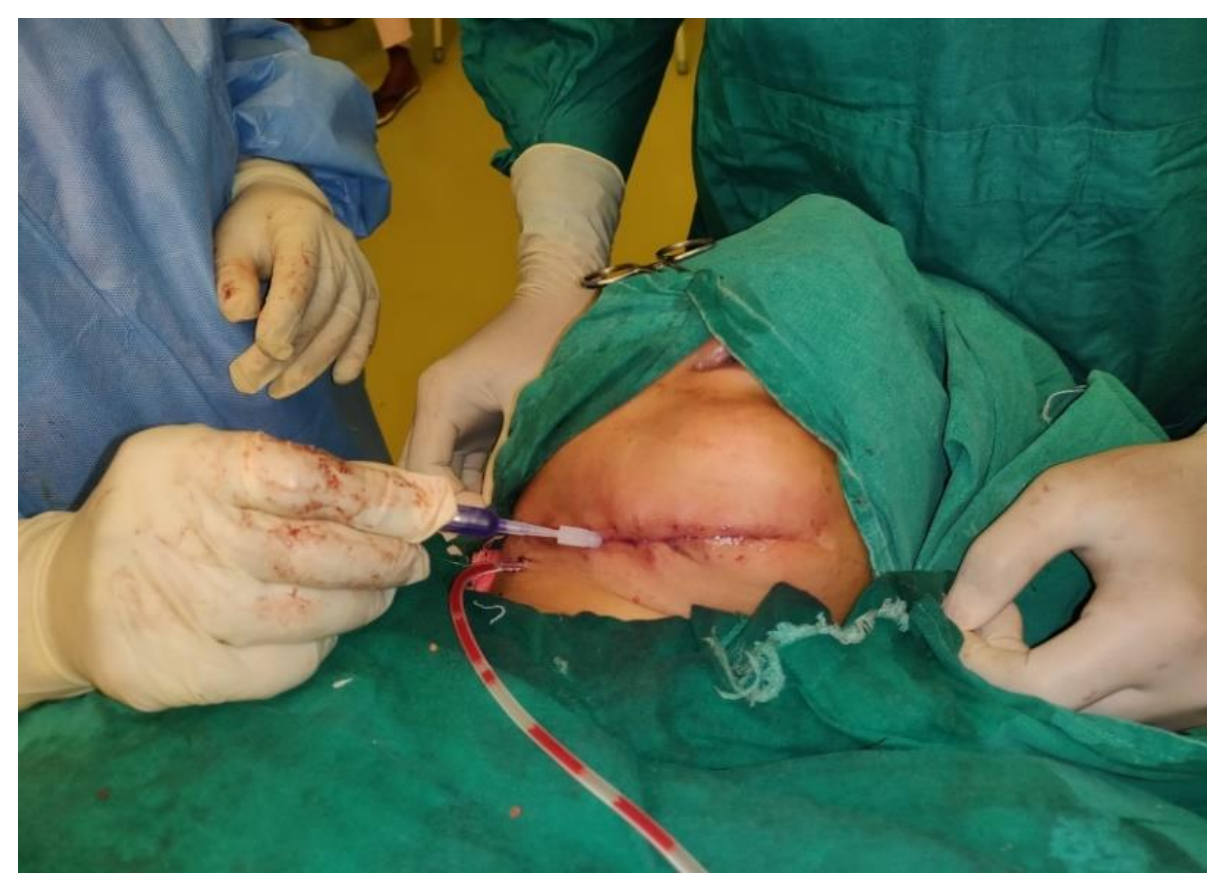

Figure 2. (Application of tissue adhesive glue)

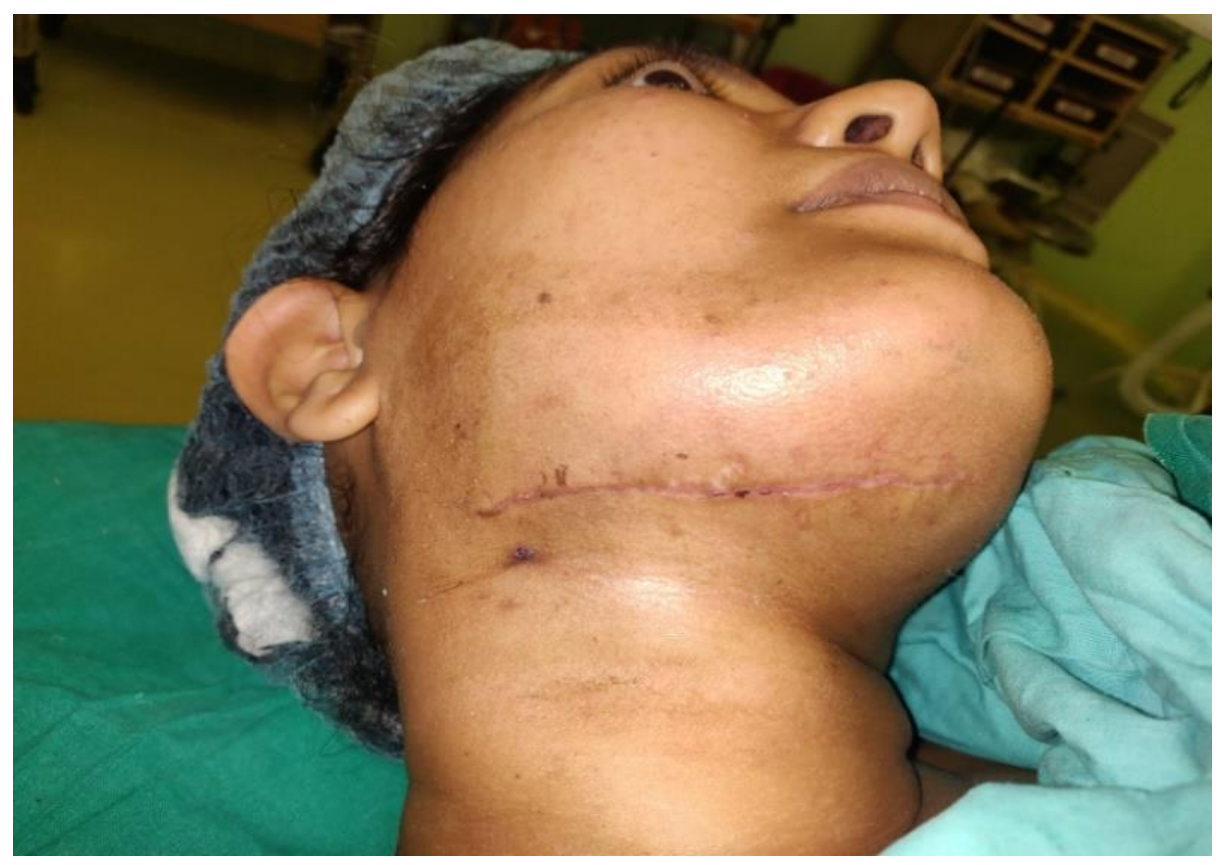

Figure 3. (Post-operative appearance of scar)

The skin was cleaned for traces of blood and debris and dried thoroughly with gauze to guard against early polymerization of the glue touching the wet surface. The edges of the wounds were held together with toothforceps so that the wounds could nicely approximate. Redrying of the wounds was carried out and then $\mathrm{N}$-butyl-2-cyanoacrylate (Histoacryl) was applied either as a continuous strip method, gently spreading the glue along the entire length of the wound. The wounds were held together for $20 \mathrm{~s}$ to allow for polymerization and bond formation of the glue to achieve skin closure, and then a second layer was applied overlapping the first layer and extending for a few millimeters away from the wound
During follow-up, wounds were examined for evidence of infection, pain and discharge, and photographs of the wounds were taken. The first and third month postoperative photographs were shown to a senior surgeon, oblivious of the technique of skin closure, to rate the scars. The senior surgeon used the 'WES scale' for rating scars. It consists of six variables and is graded on a 0 - or 1-point scale. A total cosmetic score is derived by the addition of all the scores. A score of 6 is considered optimal, whereas a score of 3-5 suboptimal or acceptable wound, and a grade of 13 is an unacceptable wound.

\section{Result}


It took less than a minute to close the wound. Final scar was also satisfactory, comparable to as achieve by suturing technique. . The senior surgeon used the 'WES scale' for rating scars and rated6/6.

\section{Discussion}

Cyanoacrylate adhesives have a common chemical structure. Different cyanoacrylate differs in the alkyl group $(-R)$ that changes the properties of each individual tissue adhesive. Cyanoacrylates are liquid monomers that can be used after surgery to form a rapid and strong adhesion. This process occurs when they come into contact with anions, such as those found in skin moisture or wound exudate. Therefore, when applied to the edges of a wound a strong bond develops, allowing wound closure.

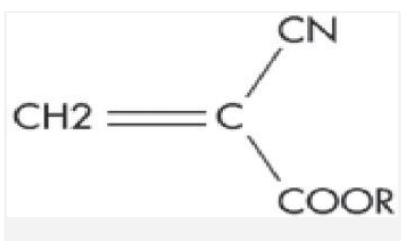

Early derivatives of cyanoacrylate has short chain alkyl derivatives, which degraded rapidly into cyanoacetate and formaldehyde. These substances gets accumulated locally in the tissues and and are responsible for inflammation seen with early products. N-butyl-2-cyanoacrylate (Histoacryl blue), has long chain alkyl group and devoid of inflammatory property. They highlighted the virtues of its ease of use, such as patient acceptability, convenience of its application, low complication rates, excellent cosmetic outcome, cost-benefit ratio and sealing wounds in pediatric patients. In addition, it also has many nonaesthetic related benefits - for example, minimizing the number of instruments on the operative field and reducing the potential of needle-prick injuries to surgeons and staff. It exists in two forms: Histoacryl and Histoacryl blue. Both forms are sterile translucent liquids for tissue adhesion. They polymerize in seconds upon being exposed to water or water-containing substances like human tissue. Histoacryl and Histoacryl blue are supplied in $0.5 \mathrm{ml}$ single patient use plastic ampoules they offer following advantage over other tissue adhesive-

- Wound closure in one minute [1, 2, 3, 4]

- $\quad$ Significant less pain than suture materials [5]

- $\quad$ Effective microbial barrier $[6,7,8]$

- $\quad$ Storage at room temperature $<22^{\circ}$

- High level of patient and physician satisfaction $[9,10]$

- Save time and costs [10, 11]

- Only one layer is needed [4]

- Histoacryl® can be used for closure of endoscopic incisions

Disadvantage of these tissue adhesive is that they are costlier than sutures. (5 to six time costlier than Vicryl suture).

\section{Conclusion}

$\mathrm{N}$-butyl-2-cyanoacrylate glue is effective method of skin closure, and has cosmetic results similar to skin closure with subcuticular sutures. This method is quick, safe and effective. It has better tolerance and better patient satisfaction... It is easily applied and could be considered an excellent alternative and an improvement on the traditional method of wound closure.. However, large randomized control trials are required to confirm the efficacy of this treatment modality.

\section{Conflicts of interest: None.}

\section{Declarations}

\section{Authors' Contributions}

All authors made contributions to the article

\section{Availability of Data and Materials}

Not applicable.

Financial Support and Sponsorship: None.

\section{Consent for Publication}

Not applicable.

\section{References}

1. Dumville JC, Coulthard P, Worthington HV, Riley P, Patel N. (2014). Tissue adhesives for closure of surgical incisions. Cochrane Database Syst Rev, 28:11

2. Koonce SL, Eck DL, Shaddix KK, Perdikis G. (2015). A prospective randomized controlled trial comparing N-butyl-2 cyanoacrylate (Histoacryl), octyl cyanoacrylate (Dermabond), and subcuticular suture for closure of surgical incisions. Ann Plast Surg, 1:107-110.

3. Lloris-Carsí JM, Ballester-Álvaro J, Barrios C, ZaragozáFernández C, Gómez-De la Cruz C. (2016). Randomized clinical trial of a new cyanoacrylate flexible tissue adhesive (Adhflex) for repairing surgical wounds. Wound Repair Regen, 3:568-580.

4. Elmasalme FN, Matbouli SA, Zuberi MS. (1995). Use of tissue adhesive in the closure of small incisions and lacerations. J Pediatr Surg, 30:837-838.

5. Farion K, Osmond MH, Hartling L, Russell K, Klassen T, Crumley E, Wiebe N. (2002). Tissue adhesives for traumatic lacerations in children and adults. Cochrane Database Syst Rev, 3:CD003326

6. Ranson JM, et al. (2016). Haemostatic property of cyanoacrylate in pedicled flaps. Br J Oral Maxillofac Surg.

7. Yulevich A, Cohen Z, Mares AJ. (1998). Use of N-Butyl-2Cyanoacrylate (HistoacrylR) in Closure of Thoracoscopic a Laparoscopic Surgical Wounds in Children. Pediatric Endosurg, 2:31-34.

8. Hovaghimian DG, Sedira KAA, Farag MY. (2015). N-butyl-2cyanoacrylate tissue adhesive versus subcuticular skin closure in external dacryocystorhinostomy, 16:97-102.

9. Edwards S, Parkinson L. (2016). Is Fixing Pediatric Nail Bed Injuries with Medical Adhesives as Effective as Suturing? A Review of the Literature. Pediatr Emerg Care.

10. Goktas N, Karcioglu O, Coskun F, Karaduman S, Menderes A. (2002). Comparison of tissue adhesive and suturing in the repair of lacerations in the emergency department. Eur $\mathrm{J}$ Emerg Med, 2:155-8. 
11. Yang J., Yong Jin Na, Yong Jung Song, Ook Hwan Choi, Sun Kyung Lee, Hwi Gon Kim. (2016). the effectiveness of laparoendoscopic single-site surgery (LESS) compared with conventional laparoscopic surgery for ectopic pregnancy with hemoperitoneum. Taiwanese Journal of Obstetrics \& Gynecology, 55:35-39
Ready to submit your research? Choose Auctores and benefit from:

* fast, convenient online submission

* rigorous peer review by experienced research in your field

* rapid publication on acceptance

* authors retain copyrights

* unique DOI for all articles

* immediate, unrestricted online access

At Auctores, research is always in progress.

Learn more www.auctoresonline.org/journals/surgical-case-reports-andimages 